THE MIGRANT DIARIES 



\title{
THE MIGRANT DIARIES
}

\author{
Lynne Jones
}

Refuge Press, New York, 2020 
Copyright (C2020 by Lynne Jones

All rights reserved.

Published in the United States by The Refuge Press

www.refugepress.com

The Refuge Press shares the registered trademark of The Center for International Humanitarian Cooperation, of which it is a part.

No part of this book may be reproduced or utilized in any form or by any means, electronic or mechanical, including photocopying and recording, or by any information storage and retrieval system without permission in writing from the publishers.

ISBN\#13: 978-0-8232-9699-6 (Hard Cover)

ISBN\#13: 978-0-8232-9698-9 (Paperback)

ISBN\#13: 978-0-8232-9700-9 (ePub)

ISBN\#13: 978-0-8232-9701-6 (WebPDF)

Cover and book design: Mauro Sarri

Cover image: Abdullah (age 9)

Printed in the United States of America. 

This book is dedicated to all those forced to leave the place they call bome. 